\title{
Measure of Macroeconomics of CFA Zone Countries Compare to SSA Countries
}

\author{
Kouame Henri Michel A.* \\ School of Finance \& economics, Jiangsu University, 301 Xuefu Rd, Jingkou District, Zhenjiang, \\ Jiangsu, China \\ * E-mail of the corresponding author: henrimichel.ka@gmail.com
}

The research is financed by the school of finance and economics of Jiangsu University (+86 51188780011$)$

\begin{abstract}
The influence of services activity in the economic development regarding the macroeconomics tactics and application. We investigate the sources of macroeconomics fluctuations in Sub-Saharan African (SSA) countries with particular attention to the development growth, federal investment, gross national income and consumer price with a structural Vector Auto regression (VAR) model with limited capital mobility and long run restrictions to identify the shocks. The research data analyzed by Linear square, in the first step data has been manipulated by level of stationary in first root and then with unit root individually classify the regions distribution with each expects to estimation development and confirm that even though the development techniques by individual development of SSA. However, terms of growth intention and development tend to influence the CFA zone to a greater extent and there seems to be a higher influence of demand shocks on output and the federal investment and consumer prices in the non-CFA countries. Supply and terms of trade shocks tend to dominate output movements in the CFA and non-CFA countries alike.
\end{abstract}

Keywords: Economic development; SSA and CFA; macroeconomics

DOI: $10.7176 /$ RJFA/11-4-11

Publication date: February $29^{\text {th }} 2020$

\section{Introduction}

This paper aim to compare the economic performance of the foreign investment by net, direct investment and industrial design application have targeted as for development of market. The indicators of industries show the value-added services and employment development as for value added growth and development. The SSA FDI investment policies showed the resources factors of infrastructure and financial factors, while the value of investment grow by different industries and it's important for social and cultural factors. (Abosedra, Arayssi, Ben Sita, \& Mutshinda, 2019)The diversifying factor cross target consumed and import versus by export driven investment. However, the private equity groups just focusing the food production, maturity of the person interest business, agriculture and they do not directly target the country profit. Searching the opportunity across the country by different names and gaining opportunities.(De \& Sun, 2019; Osakwe, Santos-Paulino, \& Dogan, 2018) The country strategies despite a commodity by driven economies likewise, Nigeria and South Africa. We illustrate the literature from the great part of the exchange rate and the consequence of a different way of investment.(Regolo, 2013) There are several issues of relationship between exchange rate and export value with misalignment and international trade. Hence, the part of the undervaluation of the exchange rate is different investing from which do not fully adjust their price of evolution of the exchange rate.(Adams \& Klobodu, 2016) The vertical integration and importer currency network of large shape in trade and investment. The final issue of the relationship between exchange rate and investment with trade and explored the effects of exchange with decision foreign ministry, especially they influence the investment rate and trade value of international trade.(Gnangnon, 2016) The monetary policies and implication of trade is satiability of CFA franc zone in African countries in the term of macroeconomic and the important issues some countries unstable and have taking weak attention of historically monetary institutional framework. However, the currencies depreciate in an external environment in the region's stability and legitimate to achieve the competitiveness of individual policies. The policies of investment in a different channel by self-crating the huge gap in monetary policies, where the different price channel has tagging different prices level, credit ratio, exchange rate cause of the intellectual policies of inflation, GDP, trade and services and merchandise trade has effected on the west African countries monetary policies. The rate of a channel determined the effects on price and exchange rate. 
This research is exploring the above phenomena regarding the sectors state on equity and develop the industries for the private use and indirectly taken all the profit from one side, it regarded as amongst the most understanding emerging market in CFA and directly forward the attention of foreign investment in different countries.(Abid, 2017; Abosedra et al., 2019; Kizuka et al., 2017) The research tests private equity and investment in CFA with resulting in its continued growth and exploring the semi-structure investment criteria. Where the industries by selfgrowing under the state law and under the government legislation is responsible to test the funding with ministry of development, the private investment creating the big gap in industries development. The important of this paper is going to highly the valuation of equity in different platform with foreign direct investment, portfolio equity, portfolio investment and a contribution rate of tax in different periods to indemnify the private equity determination as for a short period and how it effects the country situation for a long term. The valuation of investment and portfolio equity have analyzed by a generalized liner model and an individual elaborated on the evidence of future equity by different indicators. I show the national level of output in CFA progress with a collection of revenue and theory of equity showed with profitable tax. We base the period data of this research paper on 1990-2018 and as per the endpoint classify the stationary value in 2 and 3 sections. The literature of these indicators halted in section 2 and method in section 3 . The fourth part of paper purely based on analysis and in last section recommendation and conclusion have been highlighted.

\section{Literature}

FDI investigated in many empirical studies for some reviews of the literature. As noted and there are two main strands in the literature: one focuses on the FDI determinants at the micro-level and the other at the macro level of SSA, that is attractive for investors from neighboring countries because of linguistic and cultural similarities, geographic proximity and historical ties, which could explain $75 \%$ of the FDI inflows in the early years of development.(Gil-Alana, Carcel, \& Abakah, 2018; Senga, Cassimon, \& Essers, 2018) The net foreign assets, investment on plant and industries, GDP development by foreign affairs, patents and residence and provided the opportunities to the investor for the growing of financing part of national economy. The strategical tools of micro approach in investment showed the positive flow in FDI in the SSA. As comparatively, SSA countries given good examples of investment of trade and fixation of assets. The demographic trends change the polices of global competition, mass digital and global challenges by the indirect investment policies.(Kizuka et al., 2017) The quality and efficiency of wealth ageing population, quality, and budgetary condition of investment policies. The principle of wealth showed social intention and behavior regarding different investment policies and stable growth. The investment funds and change equity including the execution, monitoring and exiting be liable for all the debts and belonging of the owner who invest money privately.(Couharde, Coulibaly, Guerreiro, \& Mignon, 2013) The computed results are analyzed the positive review in taxation and equity of liquid. Furthermore, there are many useful competing theories of equity and indicating the global equity with profitable tax and shows positive review on taxation and liquid equity.(Adams \& Klobodu, 2016) The investment in SSA countries by different states showed to a flow of money from the deep resources, likewise from the net foreign assets, investment on plant and industries, GDP development by foreign affairs, patents and residence and provided the opportunities to the investor for the growing of financing part of national economy.(Cheng et al., 2017; Elbadawi \& Majd, 1996)

\section{DATA, MODEL AND RESULTS}

The research empirical model is based on panel data of 14 CFA countries and 33 SSA countries under developed countries in the period of 1990-2018. The research data analyzed by Linear square, in the first step data has been manipulated by level of stationary in first root and then with unit root individually classify the regions distribution with each expects.(Abbott, Parker, \& Peters, 2006; Budipriyanto, Wirjodirdjo, Pujawan, \& Gurning, 2017; Komchornrit, 2017) We have analyzed the alternative GDP, FDI, GNI and CPI financial statistics by dollars. The exchange rate is determined by legal sanctioned and annual average income based. The purchasing power parity has been computed by a unit of the domestic market and the results got by the exchange rate of SSA and CFA.(Budipriyanto et al., 2017) The ratio also referred to the national level. The real price nominal effective rate and weighting average of several exchange rates are divided by a price deflator or index of cost. We employed the GDP growth regarding FDI, GNI and CPI issues of countries and how they impact on economic growth of the country. The descriptive analytical study analyzed with mean deviation. 
Table 1: Mean valuation

\begin{tabular}{|c|c|c|c|c|c|}
\hline & GDP & FDI & TRADE_BALANCE & GNI & CPI \\
\hline Mean & 1.804 & 425.033 & 130.629 & 18110.180 & 82.316 \\
\hline Median & 1.808 & 82.620 & -251.527 & 5025.794 & 76.050 \\
\hline Maximum & 87.759 & 10028.220 & 63700.000 & 544708.000 & 4583.705 \\
\hline Minimum & -45.988 & -7397.295 & -30176.520 & 60.301 & 0.000 \\
\hline Std. Dev. & 6.558 & 1132.933 & 5810.808 & 52902.850 & 142.805 \\
\hline Skewness & 2.668 & 3.566 & 4.857 & 5.916 & 26.186 \\
\hline Kurtosis & 43.046 & 28.606 & 46.418 & 42.062 & 805.003 \\
\hline Jarque-Bera & 84601.730 & 36622.730 & 102605.000 & 86344.750 & 33481811.000 \\
\hline Probability & 0.000 & 0.000 & 0.000 & 0.000 & 0.000 \\
\hline Observations & 1244 & 1244 & 1244 & 1244 & 1244 \\
\hline
\end{tabular}

The highest mean value is indicating highly influence of GDP in different states, like the export mean is indicating positive significant effects on GDP compare to import and unemployment. They influence the longterm relationship between the GDP and FDI, and creating the short-run relationship with unemployment. Fig 1 as indicating the covariance relationship among the explanatory variables. The statistically analysis have determined the affiliation of FDI highest mean value.

Figure 1. Indicators with mean
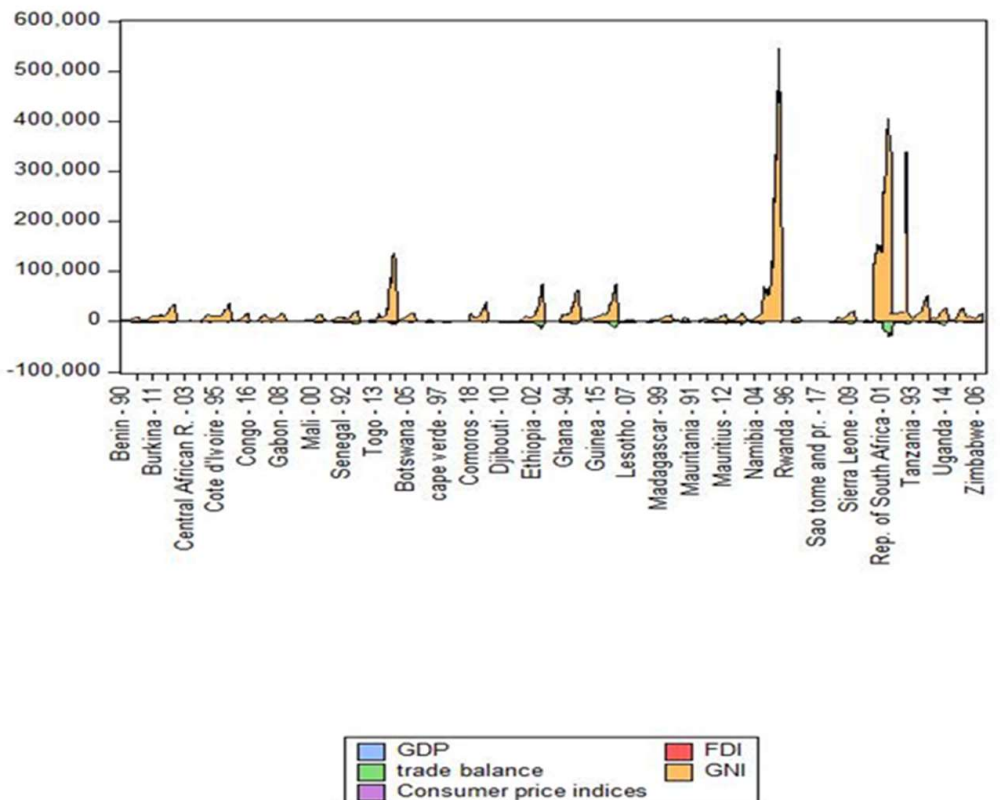
Table 2. Covariance analysis

\begin{tabular}{|l|l|l|l|l|l|}
\hline Correlation & GDP & FDI & TRADE_BALANCE & GNI & CPI \\
\hline GDP & 1 & & & & \\
\hline FDI & 0.037415 & 1 & & & \\
\hline TRADE_BALANCE & -0.004837 & 0.081724 & 1 & & \\
\hline GNI & 0.001628 & 0.646227 & 0.261116 & 1 & \\
\hline CONSUMER_PRICE_INDICES & 0.007479 & 0.060106 & -0.01823 & 0.045324 & 1 \\
\hline
\end{tabular}

Note: Table 2 indicated the covariance relationship between the existing variables, the trade balance negative impact shows the less active consumer price with GDP.

Table 3. Tabulation of GDP and FDI, Trade balance, GNI and consumer price indices

\begin{tabular}{|l|l|l|l|}
\hline GDP & 3 & & \\
\hline FDI & 5 & & \\
\hline TRADE_BALANCE & 6 & & \\
\hline GNI & 3 & & \\
\hline CONSUMER_PRICE_INDICES & 3 & & \\
\hline Product of Categories & 810 & & \\
\hline & & & Prob \\
\hline Test Statistics & df & Value & 0 \\
\hline Pearson X2 & 794 & 37861.62 & 1 \\
\hline Likelihood Ratio G2 & 794 & 352.9873 & \\
\hline
\end{tabular}

WARNING: Expected value is less than 5 in $98.77 \%$ of cells (800 of 810 ).

Table 3 indicated the relationship between the consumer variable with 793 pearson with 352.98 like wood ratio, it mean there relationship is not directly impact on the trade balance.

Table 4. Test for Equality of Medians between Series

\begin{tabular}{|c|c|c|c|c|c|}
\hline Method & & $\mathrm{df}$ & Value & \multicolumn{2}{|c|}{ Probability } \\
\hline Med. Chi-square & & 4 & 3340.489 & 0 & \\
\hline Adj. Med. Chi-square & & 4 & 3334.14 & 0 & \\
\hline Kruskal-Wallis & & 4 & 4123.063 & 0 & \\
\hline Kruskal-Wallis (tie-adj.) & & 4 & 4123.065 & 0 & \\
\hline van der Waerden & & 4 & 3977.718 & 0 & \\
\hline Variable & Count & Median & Median & $\begin{array}{l}\text { Mean } \\
\text { Rank }\end{array}$ & $\begin{array}{l}\text { Mean } \\
\text { Score }\end{array}$ \\
\hline
\end{tabular}




\begin{tabular}{|l|l|l|l|l|l|}
\hline GDP & 1334 & 1.704663 & 4 & 1884.014 & -0.586092 \\
\hline FDI & 1327 & 83.76809 & 782 & 3718.38 & 0.161915 \\
\hline TRADE_BALANCE & 1359 & -260.22 & 292 & 1624.419 & -0.954014 \\
\hline GNI & 1289 & 4673.444 & 1289 & 5828.852 & 1.311314 \\
\hline CONSUMER_PRICE_INDICES & 1327 & 77.08966 & 951 & 3657.14 & 0.130525 \\
\hline All & 6636 & 47.94097 & 3318 & 3318.5 & $-2.13 \mathrm{E}-09$ \\
\hline
\end{tabular}

Table 4 shows that the highest mean valuation of GNI with all indicators, $2^{\text {nd }}$ the FDI, GDP and CPI taking less effect on trade balance and it is refereeing the granger causality among explanatory variables and the development does not either exists which is logical given that it is a long-run concept with unemployment in the short-run contributes to more Economic Performance with SAS.

Figure 2. AR inversed root

Inverse Roots of AR Characteristic Polynomial

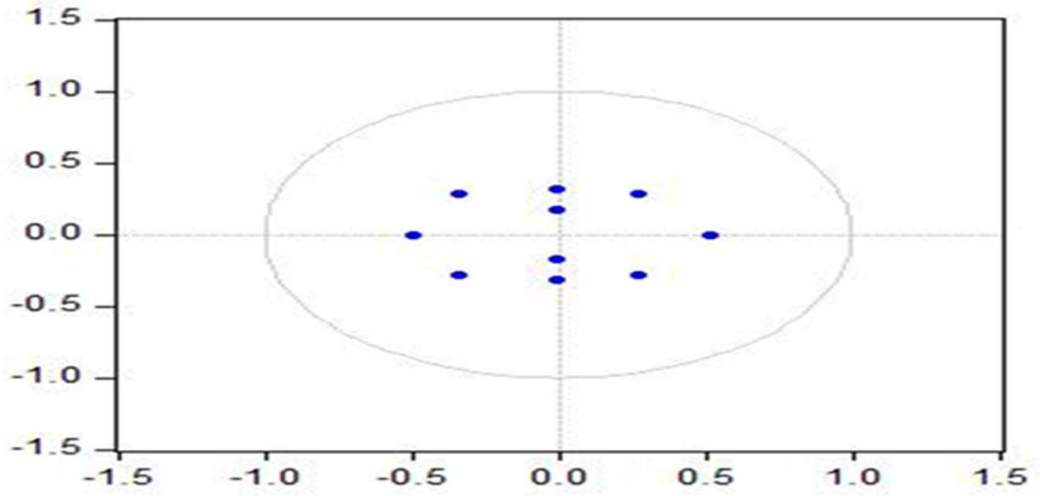

Table 5. Pedroni Residual Cointegration Test

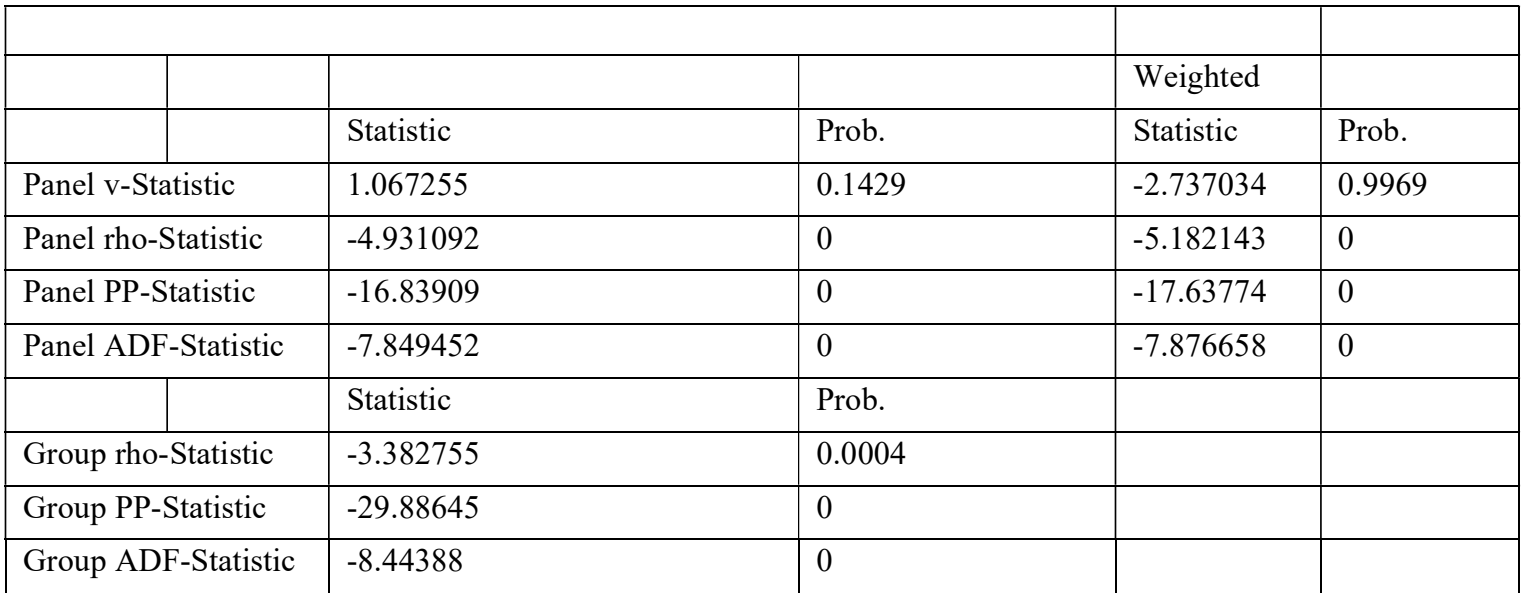

Table 5 shows that the unit root test with perdroni cointegration test with probable of .99 value. Furthermore, the GDP effects to change the development policies by different impact of variables. Unemployment does not granger casualty on export but vice versa of export, like import does not Granger casualty on export. However, the evolution of per capita economic performance, per capita GDP without services and per capita services GDP.(Devarajan \& de Melo, 1987; Kato \& Uctum, 2008) 
Figure 3. Impulse valuation
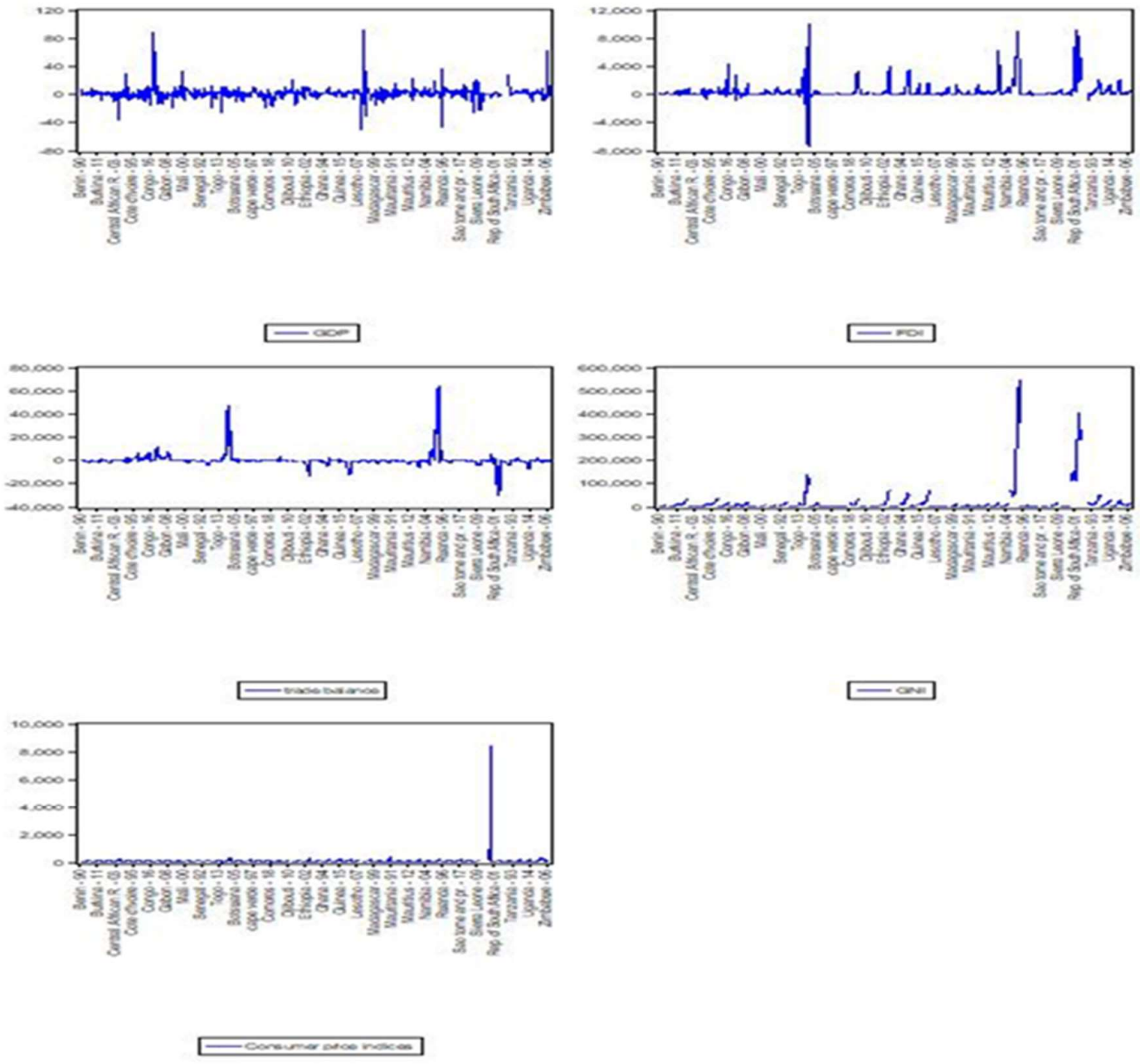
Figure 4. Individual Weight

Histarical Docampas fon using Cholesky (d $f$ ad ustod) Weights
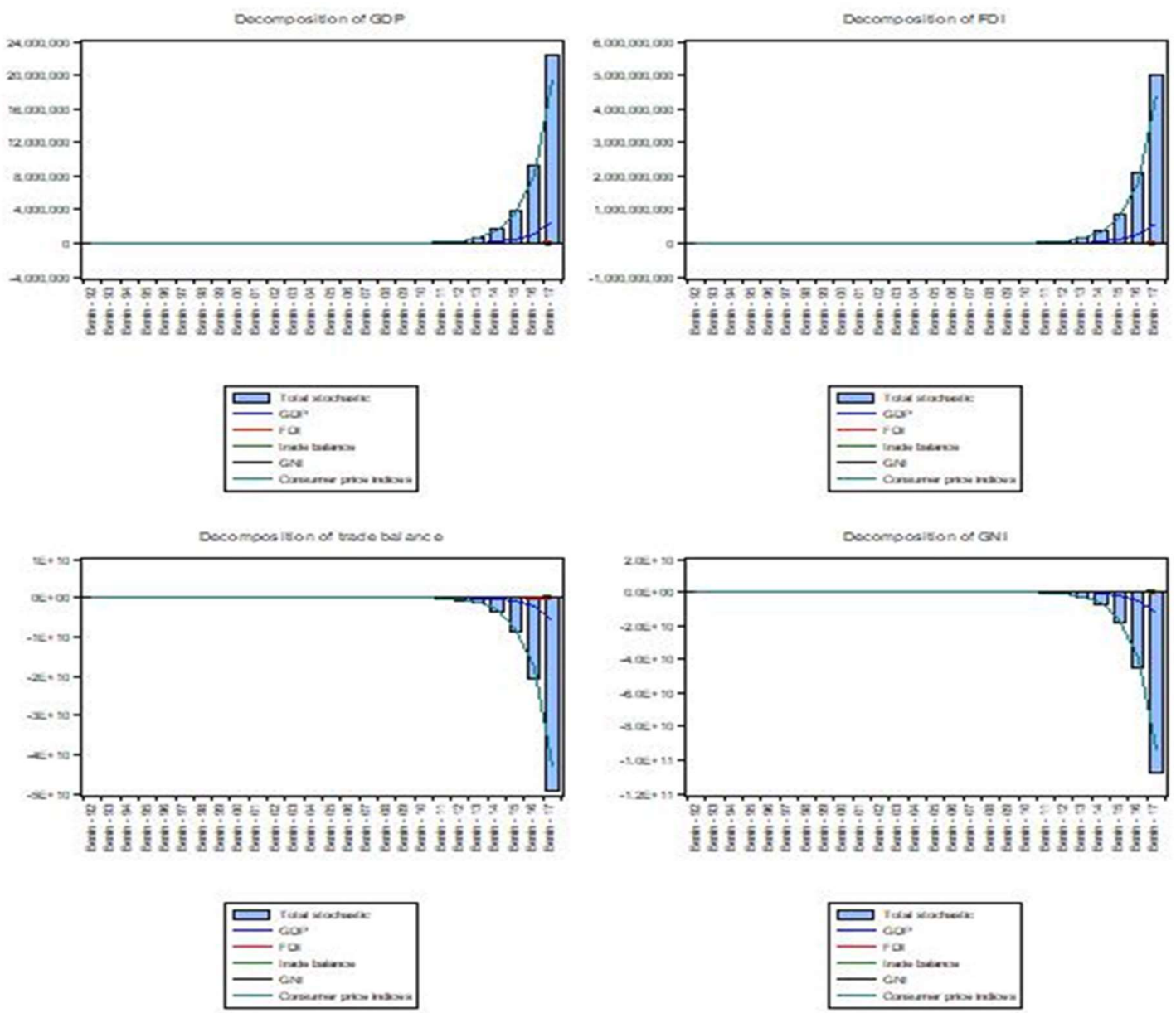

Decompobition of Conaumerpence indices
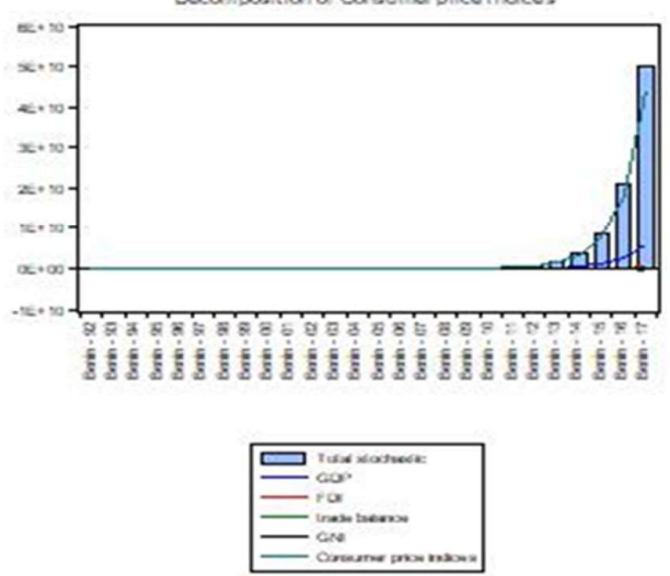
Table 6. Granger test

\begin{tabular}{|c|c|c|c|}
\hline \multicolumn{4}{|l|}{ Pairwise Granger Causality Tests } \\
\hline Null Hypothesis: & Obs & F-Statistic & Prob. \\
\hline FDI does not Granger Cause GDP & 1223 & 0.03721 & 0.9635 \\
\hline GDP does not Granger Cause FDI & & 1.76625 & 0.1714 \\
\hline TRADE_BALANCE does not Granger Cause GDP & 1240 & 0.37819 & 0.6852 \\
\hline GDP does not Granger Cause TRADE_BALANCE & & 0.07391 & 0.9288 \\
\hline GNI does not Granger Cause GDP & 1192 & 0.55221 & 0.5758 \\
\hline GDP does not Granger Cause GNI & & 0.24064 & 0.7862 \\
\hline CONSUMER_PRICE_INDICES does not Granger Cause GDP & 1208 & 0.23832 & 0.788 \\
\hline GDP does not Granger Cause CONSUMER_PRICE_INDICES & & 0.07461 & 0.9281 \\
\hline TRADE_BALANCE does not Granger Cause FDI & 1226 & 0.96469 & 0.3814 \\
\hline FDI does not Granger Cause TRADE_BALANCE & & 22.1606 & $4.00 \mathrm{E}-10$ \\
\hline GNI does not Granger Cause FDI & 1178 & 82.2497 & $4.00 \mathrm{E}-34$ \\
\hline FDI does not Granger Cause GNI & & 57.9335 & $1.00 \mathrm{E}-24$ \\
\hline CONSUMER_PRICE_INDICES does not Granger Cause FDI & 1194 & 0.52773 & 0.5901 \\
\hline FDI does not Granger Cause CONSUMER_PRICE_INDICES & & 0.18229 & 0.8334 \\
\hline GNI does not Granger Cause TRADE_BALANCE & 1195 & 47.0972 & $2.00 \mathrm{E}-20$ \\
\hline TRADE_BALANCE does not Granger Cause GNI & & 22.5665 & $2.00 \mathrm{E}-10$ \\
\hline $\begin{array}{lllll}\text { CONSUMER_PRICE_INDICES } & \text { does } & \text { not } & \text { Granger } & \text { Cause } \\
\text { TRADE_BALANCE } & & & & \end{array}$ & 1233 & 0.66255 & 0.5157 \\
\hline TRADE_BALANCE does not Granger Cause CONSUMER_PRICE_INDIC & & 0.1366 & 0.8723 \\
\hline CONSUMER_PRICE_INDICES does not Granger Cause GNI & 1163 & 0.23783 & 0.7884 \\
\hline GNI does not Granger Cause CONSUMER_PRICE_INDICES & & 1.45665 & 0.2334 \\
\hline
\end{tabular}

Granger causality test indicated with consumer prices, GDP, GNI and other indicators, the valuation of per economic performance per capita GDP without services and per capita services GDP. All the three variables are expressed in terms of 2011 indices. 
Table 7. Vector auto regression

\begin{tabular}{|c|c|c|c|c|c|}
\hline & GDP & FDI & TRADE_BALANCE & GNI & CONSUMER_PRICE_INDICES \\
\hline \multirow[t]{3}{*}{ GDP(-1) } & 0.226098 & 4.83806 & 4.072177 & 13.77988 & -0.168367 \\
\hline & -0.02931 & -3.46786 & -10.4848 & -33.9083 & -0.16188 \\
\hline & [ 7.71496] & [ 1.39511$]$ & [ 0.38839] & [0.40639] & {$[-1.04009]$} \\
\hline \multirow[t]{3}{*}{ GDP(-2) } & 0.116565 & 2.275085 & 7.613825 & 15.95938 & -0.059839 \\
\hline & -0.02906 & -3.43896 & -10.3974 & -33.6257 & -0.16053 \\
\hline & [ 4.01089] & {$[0.66156]$} & {$[0.73228]$} & {$[0.47462]$} & {$[-0.37276]$} \\
\hline \multirow[t]{3}{*}{ FDI(-1) } & 0.000148 & 0.57856 & -0.048792 & -0.224979 & 0.000171 \\
\hline & -0.00026 & -0.03115 & -0.09418 & -0.30457 & -0.00145 \\
\hline & {$[0.56362]$} & [ 18.5739] & {$[-0.51810]$} & {$[-0.73867]$} & [ 0.11727] \\
\hline \multirow[t]{3}{*}{ FDI(-2) } & 0.000137 & -0.062489 & 0.938338 & 3.042437 & -0.001941 \\
\hline & -0.00027 & -0.03225 & -0.0975 & -0.31532 & -0.00151 \\
\hline & {$[0.50378]$} & {$[-1.93774]$} & [ 9.62393] & [ 9.64866] & {$[-1.28935]$} \\
\hline \multirow[t]{3}{*}{ TRADE_BALANCE(-1) } & $-1.91 \mathrm{E}-05$ & -0.021473 & 1.018897 & 0.541216 & $-9.45 \mathrm{E}-06$ \\
\hline & $-8.90 \mathrm{E}-05$ & -0.01055 & -0.0319 & -0.10317 & -0.00049 \\
\hline & {$[-0.21419]$} & {$[-2.03515]$} & [31.9404] & [5.24605] & {$[-0.01919]$} \\
\hline \multirow[t]{3}{*}{ TRADE_BALANCE(-2) } & $-1.21 \mathrm{E}-05$ & 0.007803 & -0.033411 & -0.334623 & $2.74 \mathrm{E}-05$ \\
\hline & $-8.70 \mathrm{E}-05$ & -0.01034 & -0.03126 & -0.10109 & -0.00048 \\
\hline & {$[-0.13855]$} & [ 0.75481] & {$[-1.06891]$} & {$[-3.31027]$} & {$[0.05677]$} \\
\hline \multirow[t]{3}{*}{ GNI(-1) } & $2.87 \mathrm{E}-05$ & 0.029334 & -0.103487 & 1.162892 & $1.38 \mathrm{E}-06$ \\
\hline & $-2.70 \mathrm{E}-05$ & -0.00325 & -0.00984 & -0.03181 & -0.00015 \\
\hline & [ 1.04421$]$ & [ 9.01676$]$ & {$[-10.5214]$} & [ 36.5578] & {$[0.00911]$} \\
\hline \multirow[t]{3}{*}{ GNI(-2) } & $-3.48 \mathrm{E}-05$ & -0.023195 & 0.088854 & -0.192923 & $-1.07 \mathrm{E}-05$ \\
\hline & $-2.80 \mathrm{E}-05$ & -0.00333 & -0.01008 & -0.0326 & -0.00016 \\
\hline & {$[-1.23655]$} & [-6.95807] & [ 8.81587] & {$[-5.91867]$} & {$[-0.06900]$} \\
\hline \multirow[t]{3}{*}{ CONSUMER_PRICE_INDICES(-1) } & 0.003584 & -0.08663 & 0.346463 & 2.044392 & 3.330067 \\
\hline & -0.00502 & -0.59451 & -1.79746 & -5.81308 & -0.02775 \\
\hline & {$[0.71341]$} & {$[-0.14572]$} & [0.19275] & [0.35169] & [ 119.995] \\
\hline
\end{tabular}




\begin{tabular}{|c|c|c|c|c|c|}
\hline CONSUMER_PRICE_INDICES(-2) & -0.006342 & 0.701178 & -4.543349 & -10.9531 & -2.242409 \\
\hline & -0.00752 & -0.88953 & -2.6894 & -8.69769 & -0.04152 \\
\hline & {$[-0.84366]$} & {$[0.78826]$} & {$[-1.68935]$} & {$[-1.25931]$} & {$[-54.0044]$} \\
\hline $\mathrm{C}$ & 1.362813 & 45.06882 & 242.0058 & 765.4051 & -9.47305 \\
\hline & -0.3752 & -44.3974 & -134.231 & -434.112 & -2.07245 \\
\hline & {$[3.63227]$} & {$[1.01512]$} & {$[1.80290]$} & {$[1.76315]$} & {$[-4.57095]$} \\
\hline R-squared & 0.086629 & 0.595781 & 0.86072 & 0.982262 & 0.944256 \\
\hline Adj. R-squared & 0.07856 & 0.59221 & 0.85949 & 0.982105 & 0.943764 \\
\hline Sum sq. resids & 45479.51 & $6.37 \mathrm{E}+08$ & $5.82 \mathrm{E}+09$ & $6.09 \mathrm{E}+10$ & 1387607 \\
\hline S.E. equation & 6.338474 & 750.0392 & 2267.673 & 7333.786 & 35.01144 \\
\hline F-statistic & 10.73649 & 166.8461 & 699.5514 & 6268.504 & 1917.528 \\
\hline Log likelihood & -3727.027 & -9183.124 & -10447.72 & -11789.3 & -5680.457 \\
\hline Akaike AIC & 6.54073 & 16.08771 & 18.30047 & 20.64795 & 9.958804 \\
\hline Schwarz SC & 6.589248 & 16.13622 & 18.34899 & 20.69647 & 10.00732 \\
\hline Mean dependent & 1.858919 & 459.1292 & 138.5288 & 19033.93 & 86.34558 \\
\hline S.D. dependent & 6.603151 & 1174.534 & 6049.596 & 54823.09 & 147.6396 \\
\hline Determinant resid covariance (dof adj.) & & $6.07 \mathrm{E}+24$ & & & \\
\hline Determinant resid covariance & & $5.79 \mathrm{E}+24$ & & & \\
\hline Log likelihood & & -40694.66 & & & \\
\hline Akaike information criterion & & 71.303 & & & \\
\hline Schwarz criterion & & 71.54559 & & & \\
\hline Number of coefficients & & 55 & & & \\
\hline
\end{tabular}

Table 7 is indicating the long-run estimates for the economic flow with turning points of import, export and unemployment regarding per-capita GDP by the VAR. The turning point from which more per capita GDP means less Economic performance is calculated approximately would correspond to per capita GDP in form of modified and restructured model from per-capita GDP. 
Figure 5 Cholesky of indicators
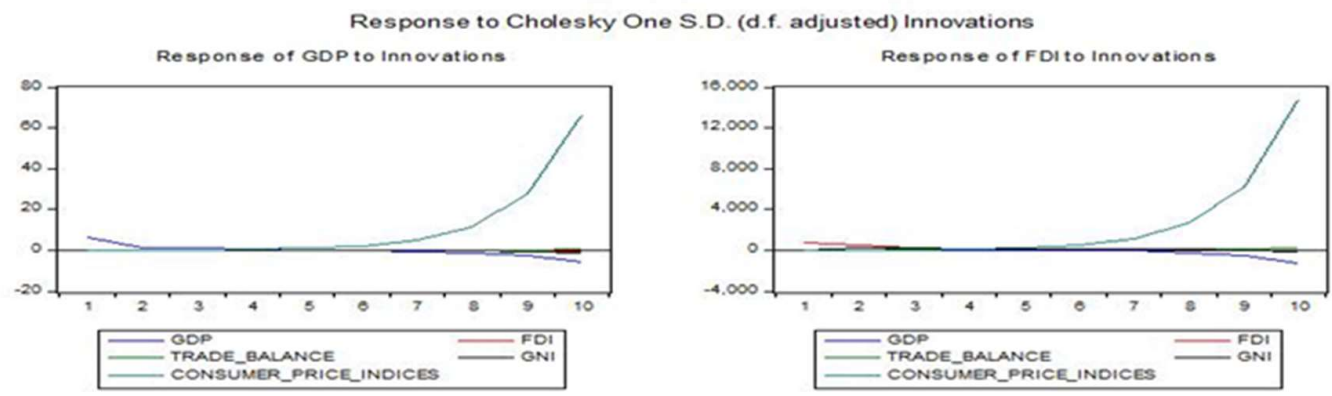

Response of TRADE_BALANCE to Innovations
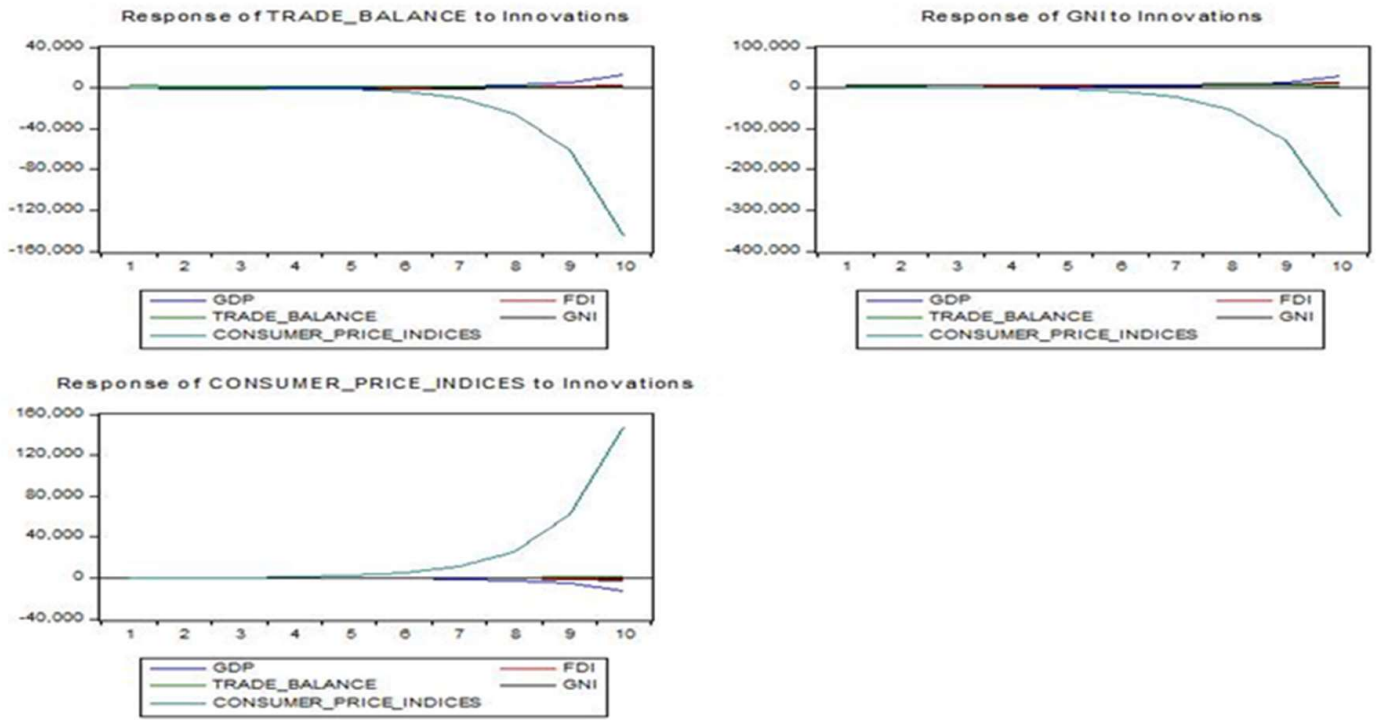

(Giannone, Kapetanios, \& McCracken, 2019; Hassani, Rua, Silva, \& Thomakos, 2019) Cholesky test is indicating the orthogonalization of skewness with chi-sq, where the probability is less than 0.05 . However, as an influential variable the long run relationship shows significant effects on valuation of SAS countries. The $1 \%$ increase in magnitude of services activities the Economic performance diminish 5.4 in second components. However, the casualty support a unidirectional relationship going from either the GDP with bidirectional causality with GDP in Robust technique and it became fundamental in order to reduce the economic performance. Table 8 and the maximum like wood indicated in Table 9 with 325.0199. 
Table 8. Chelsey orthogonalization test

\begin{tabular}{|c|c|c|c|c|}
\hline \multicolumn{4}{|c|}{ Orthogonalization: Cholesky (Lutkepohl) } & \multirow[b]{2}{*}{ Prob.* } \\
\hline Component & Skewness & Chi-sq & df & \\
\hline 1 & 2.81167 & 1378.19 & 1 & 0 \\
\hline 2 & 0.176334 & 5.420666 & 1 & 0.0199 \\
\hline 3 & -1.412859 & 347.9991 & 1 & 0 \\
\hline 4 & -0.905551 & 142.9574 & 1 & 0 \\
\hline 5 & 19.85446 & 68722.1 & 1 & 0 \\
\hline Joint & & 70596.66 & 5 & 0 \\
\hline Component & Kurtosis & Chi-sq & df & Prob. \\
\hline 1 & 45.92329 & 80298.33 & 1 & 0 \\
\hline 2 & 36.36514 & 48518.37 & 1 & 0 \\
\hline 3 & 60.97153 & 146470.4 & 1 & 0 \\
\hline 4 & 69.13838 & 190645.9 & 1 & 0 \\
\hline 5 & 551.8534 & 13129043 & 1 & 0 \\
\hline Joint & & 13594977 & 5 & 0 \\
\hline Component & Jarque-Bera & $\mathrm{df}$ & Prob. & \\
\hline 1 & 81676.52 & 2 & 0 & \\
\hline 2 & 48523.8 & 2 & 0 & \\
\hline 3 & 146818.4 & 2 & 0 & \\
\hline 4 & 190788.9 & 2 & 0 & \\
\hline 5 & 13197766 & 2 & 0 & \\
\hline Joint & 13665573 & 10 & 0 & \\
\hline \multicolumn{5}{|c|}{ *Approximate $\mathrm{p}$-values do not account for coefficient } \\
\hline estimati & & & & \\
\hline
\end{tabular}


Table 9. Factor Method: Maximum Likelihood

\begin{tabular}{|l|l|l|l|}
\hline \multicolumn{5}{|l}{} & Communality & \multicolumn{1}{l|}{ Uniqueness } \\
\hline RESID01 & 0 & 1 & \\
\hline RESID02 & 0 & 1 & \\
\hline RESID03 & 0 & 1 & \\
\hline RESID04 & 0 & 1 & \\
\hline RESID05 & 0 & 1 & \\
\hline & & & \\
\hline & Model & Independence & Saturated \\
\hline Discrepancy & 0.28523 & 0.28523 & 0 \\
\hline Chi-square statistic & 325.7329 & 325.7329 & --- \\
\hline Chi-square prob. & 0 & 0 & --- \\
\hline Bartlett chi-square & 325.0199 & 325.0199 & --- \\
\hline Bartlett probability & 0 & 0 & --- \\
\hline Parameters & 5 & 5 & 15 \\
\hline $\begin{array}{l}\text { Degrees-of- } \\
\text { freedom }\end{array}$ & 10 & 10 & \\
\hline
\end{tabular}

\section{Conclusion}

The present research demonstrates the influence of economic flow of SSA and CFA. It showed a significant influence on the growth and internal policies of government issues. The method of the real price shows the nominal GDP, GNI and FDI, the service economy which used during in one year and also include the good or services. The expected outcomes of public policies and practice showed the influence of monitoring policies with comprehensive pioneering strategies of exchange rate, the non-linarite and pass through effect the volatility on the evolution of economic performance with GNI and GDP. To this end we focus on a different approach of the gross development product model where the added value of services is isolated from total GDP. This analysis has been implemented for 14 and 33 countries in the period between 1990-2017. The above analysis is investigated the domestic credit to private sector with percentage of GDP and also shows the effect the industrial design application but the patent application has directly effect on Foreign direct investment of country. The developed countries economical condition is highly invested and mature comparatively undeveloped countries, the strategical tools of micro approach in investment indicated the positive flow in FDI in the SSA and CFA. The result shows that evolution of services with GDP and unemployment factors. The individual zones strategies directly effect on the growth of countries with explanatory variables, the tabulation of indicators determined T-test computed in granger causality. The prior most studies are showing the potential simultaneity, and unobserved country specific growth regarding the financial department and trade in monitoring policies. This research paper has signposted the economic performance and change factors by zone wise. Furthermore, the long run sustainability effects explore between expanding variables and shows positive effects in both zone. 


\section{References}

\section{Bibliography}

Abbott et al. (2006). Earnings Management, Litigation Risk, and Asymmetric Audit Fee Responses. AUDITING: A Journal of Practice \& Theory, 25(1), 85-98. doi:10.2308/aud. a journal of practice \& theory, 85-98.

Abid. M. (2017). Does economic, financial and institutional developments matter for environmental quality? A comparative analysis of EU and MEA countries. journal of environmental management, 183-194.

Abosedra et. al (2019). Exploring GDP growth volatility spillovers across countries. Economic Modelling. doi:https://doi.org/10.1016/j.econmod.2019.11.015

Adam et al. (2016). Remittances, regime durability and economic growth in Sub-Saharan Africa (SSA). Economic Analysis and Policy, 1-8.

Devarajan and De melo. (1987). Evaluating participation in African monetary unions: A statistical analysis of the CFA Zones. World Development, 15(4), 483-496.

Hassani et al. (2019). Monthly forecasting of GDP with mixed-frequency multivariate singular spectrum analysis. International Journal of Forecasting, 35(4) doi:https://doi.org/10.1016/j.ijforecast.2019.03.021, 12631272 .

K. et. al (2017). An Alkynyl-Fucose Halts Hepatoma Cell Migration and Invasion by Inhibiting GDP-FucoseSynthesizing Enzyme FX, TSTA3. Cell Chemical Biology, 24(12), doi:https://doi.org/10.1016/j.chembiol.2017.08.023, 1467-1478.e1465.

Kato et.al (2007.01). Choice of exchange rate regime and currency zones. International Review of Economics \& Finance, 17(3),. doi:https://doi.org/10.1016/j.iref., 436-456.

Budipriyanto, A et al . (2017). A Simulation Study of Collaborative Approach to Berth Allocation Problem under Uncertainty. The Asian Journal of Shipping and Logistics, 127-139.

Cheng et Al. (2017). Optimization of gaseous fuel injection for saving energy consumption and improving imbalance of heat distribution in iron ore sintering. Applied Energy, 207, , 230-242.

Couharde. (2013). Revisiting the theory of optimum currency areas: Is the CFA franc zone sustainable? Journal of macroeconomics 38, 428-441.

DE, K et al. (2019). Is the exchange rate a shock absorber or a source of shocks? Evidence from the U.S. Economic Modelling.

Giannone . (2019). Editorial: Central bank forecasting. International Journal of Forecasting, 35(4),doi:https://doi.org/10.1016/j.ijforecast.2019.08.001, 1561-1553.

gil-alana. (2018). On the linkages between Africa's emerging equity markets and global markets: Evidence from fractional integration and cointegration. Review of Development Finance, 8(2),doi:https://doi.org/10.1016/j.rdf.2018.11.003, 96-105.

Gnangnon. (2016). Aid for Trade and trade tax revenues in developing countries. Economic Analysis and Policy,50 doi:https://doi.org/10.1016/j.eap.2016.02.002, 9-22.

Komchornrit, K. (2017). The Selection of Dry Port Location by a Hybrid CFA-MACBETH-PROMETHEE Method: A Case Study of Southern Thailand. The Asian Journal of Shipping and Logistics, 33(3), . doi:https://doi.org/10.1016/j.ajsl.2017.09.004, 141-153.

Majd, E. \&. (1996). Adjustment and economic performance under a fixed exchange rate: A comparative analysis of the CFA zone. World Development, 24(5), 939-951. doi:https://doi.org/10.1016/0305-750X(96)000125 .

Osakwe et al. (2018.09.001). Trade dependence, liberalization, and exports diversification in developing countries. doi:https://doi.org/10.1016/j.joat. . Journal of African Trade, 5(1),, 19-34.

Regolo. J. (2013). Export diversification: How much does the choice of the trading partner matter? , doi:https://doi.org/10.1016/j.jinteco.2013.07.004. Journal of International Economics, 91(2), 329-342.

Senga, C., Cassimon, D., \& Essers, D. . (.2018.05.005). Sub-Saharan African Eurobond yields: What really matters beyond global factors? , doi:https://doi.org/10.1016/j.rdf. Review of Development Finance, 8(1), 49-62. 